\title{
Research on the Impact of Jeju Rural Area's Changing Funeral Ritual about Shrouds
}

\author{
Sookhee Kwon ${ }^{\dagger}$ \\ Dept. of Clothing \& Textile, Jeju National University; Jeju, Korea
}

\begin{abstract}
The objective of this research is to find out status and consciousness about shrouds according to changes of Jeju's rural funeral ritual while reviewing Jeju's traditional shrouds. Consciousness of customs regarding tradition is much stronger in Jeju Island. Since it was said that shrouds and changes of funeral ritual have very systematic correlation according to the result of precedent researches, changes of funeral rituals of Jeju's rural area were examined. At the same time, consciousness about traditional shrouds of Jeju people was also studied. As the result of examination through literary investigation, visits to rural homes, visits to production places of Jeju's shrouds and interviews with grandmothers designated as human cultural assets of traditional Jeju shrouds, etc, it was found out that Jeju's rural funeral rituals had been rapidly changed since 2000 . Traditional Jeju shrouds are also disappearing. In particular, old women of Jeju have considered preparation of their own and their husbands' shrouds in advance as a virtue. However, as it gradually became more difficult to produce and prepare traditional shrouds at homes and as the space of funeral was changed from their own houses to hospitals and/or commercial funeral homes, it was found out that a ratio of people's using general shrouds sold in market was increased and it is believed that this kind of trend will be accelerated more and more in the future.
\end{abstract}

Key words: traditional shroud, Jeju's rural funeral culture, production of shrouds, funeral space

\section{Introduction}

Early documents regarding dressing of Jeju people show that Jeju had established its dressing culture unique only for Jeju due to natural environment and geological conditions of Jeju Island. This unique dressing of Jeju had formed new dressing culture through mixture of Jeju styles with external elements due to frequent exchanges of cultural products with outside regions.

In particular, occupation and ruling of Mongo during the period of Goryeo, powerful local governance during the period of Joseon and exiles of Confucian scholars to Jeju had affected lots of impacts in all areas of Jeju life. Like this, dressing ceaselessly changes and disappears just like an organism not only under natural environment but also under social environment such as politics, economy, religion, social system, etc. In addition, it is necessary to correctly understand and revive the meaning of traditional culture of Jeju when there are special rites because they are all originated from custom.

Shrouds or afterlife clothes are called as 'Hosang clothes' in Jeju and in case of women, Jang clothes(a kind of long hood formerly worn by Korean women), which was put on during wedding ceremonies, and in case of men, Dopo(Korean full-dress attire), which is the biggest clothes, was used as shrouds. That is, clothes, which was put on during wedding, was put on during one's 60th birthday

$\dagger$ Corresponding author; Sookhee Kwon

Tel. +82-17-277-7824, Fax. +82-64-725-2591

E-mail: sookhee@jejunu.ac.kr party and was put on again as Hosang clothes when one passes away.

In general, hemp cloth was preferred as material of shrouds in other regions but in Jeju, silk was used a lot. If it is difficult to prepare shrouds in silk, Jeju people used hemp cloth for their shrouds but they never used cotton or ramie cloth and synthetic fiber. It shows very different styles according to Jeju's unique custom distinguished from other regions.

Funeral rites mean ceremonial procedure of various ancestral ritual formalities starting from burial of corpse and preparing cemetery upon the moment of one's death to the time when people return to normal life after morning the death by relatives by wearing shrouds for a certain period(Nam, 2002).

Since ancient time in Korea, it was called as Gwanhonsangje(the four ceremonial occasions of coming of age, wedding, funeral, and ancestral rites). The four ceremonies of coming of age, wedding, funeral rites and ancestral ritual formalities were regarded as important rituals. Among them, funeral rites, which are rituals for death people, and ancestral ritual formalities were considered as more important as worship for ancestors(Lee, 2006). However, funeral rites are different according to people and religion and accordingly, contents, procedure and underlying perception of rituals are all different. It is caused from difference of views of the world and views of afterlife(Lee \& Lee, 2011). However, any people or religion has perception of death as a new start of a new life in next world and their own rituals expressing such perception without thinking death as a simple completion of biological life. It was 
our tradition and custom for bereaved family to prepare and conduct courtesy with sincerity for the last hours of the deceased when bidding farewell to the deceased. However, this practice is disappearing as professional funeral homes are established commercially. After all, it is acutely necessary to have more profound research on funeral rites in order to find out views of the world as well as social consciousness of Korea. Citizens' movement, which was started around 10 years ago under the slogan of efficiency of occupation of national territory, has encouraged cremation, donation of corpse, organs and eyeball. This played a big role in changing consciousness of the national people and consequently lots of changes are appearing("Survey of Consciousness on Funeral Culture", 2008). Under this changing reality, it is necessary to analyze consciousness about traditional shrouds with strong local character together with the flow of funeral culture of Jeju rural area.

Traditional customary rituals are much stronger especially in Jeju's rural area. The objective of this research is to find out consciousness and status about shrouds according to changes of Jeju's rural culture about funeral rituals. According to the result of precedent researches, it was said that changes of shrouds and culture of funeral rituals had very systematic correlation. Therefore, it was intended to investigate Jeju people's consciousness about traditional shrouds.

\section{Methodology}

The first investigation was carried out from May 2004 to April 2005 and the second was investigated from May 2011 to April 2012 through various methods such as examination of literatures for changes of funeral rituals, visits to production places of Jeju shrouds and interviews with housewives, who have experienced Jeju's rural funeral rituals, and interviews with grandmothers who were designated as human cultural assets of producing Jeju's unique shrouds, etc. The interview was carried out with simple contents(Table 1) which can find out consciousness of Jeju people about Jeju traditional shrouds and preparation or not of one's own shroud with the target of people between 40 70 years old(Two persons in their forties, three in their fifties, five in their sixties and two persons in their seventies).

\section{Theoretical Background}

\subsection{Funeral rituals of Korea}

Korean funeral culture was family courtesy and was conducted for a long time per each family in each local region. The funerals were mainly influenced by religions such as shamanism, Buddhism and Confucianism. Burials were widely spread until now from the customs of Confucianism. Literary examination on burials and recent trend of cremation are as below.

\subsubsection{Burials}

The oldest type of a tomb is a dolmen and it is estimated as a joint vault of corpse which was prevalent from the 10th century B.C.(Before Christ) to the third century. Dolmens are discovered in numerous places throughout the country(Chung, 1990).

Characteristics of funeral systems before the period of the Three States are customs of duplicate funeral rituals and a joint cemetery system. Duplicate funeral rituals are putting only skeletal bones into a coffin after collecting only remains upon decaying corpses after burying when people die. A joint cemetery system was a family cemetery system which corpses of all family members were put into a coffin together after collecting remains when people $\operatorname{die}$ (Yang, 2010). Even during the period of the Three States, there were differences per each country. People were mainly buried when they die but during the period of unified Shilla, cremation method became popular due to impacts of Buddhism. After cremation, skeletal bones were scattered or buried. During the period of Goryeo, it was the period when cremation, which was Buddhism style, feng shui style and Confucian funeral culture coexisted(Cho, 2002).

However, during the period of Joseon, Confucian style feng shui funeral custom became a main stream and due to the policy of depressing Buddhism and encouraging Confucianism, cremation was prohibited and burial systems were enforced strongly. Cemetery feng shui religion became very popular during the late period of Joseon. From this time, a system of one's family grave sites had started and luxurious tombs had begun to appear as grave sites had become enlarged.

Chung(1990) reviewed the burial custom of the time, which was possible because population was not many and it was an agrarian society. But it is the reality of our current funeral ritual culture which is deeply rooted in Korean society and continues until now.

\subsubsection{Cremation}

Cremation means to burn corpses and process the remains. There are two methods of scattering cremated remains in mountains and rivers or ocean after pulverizing and of placing in specific places or burying underground by containing the pulverized ashes in a container. Cremation culture is an old and long funeral culture, which was existed since the ancient time of the period of the Three States, and its chronological change history is as follow(Chang, 1980).

\subsubsection{The period of the Three States}

It is difficult to confirm cremation of Goguryeo period because there exists no literature or relics. However, origination of Baekje 
cremation is estimated around the early time of the seventh century because Gaewontongbo(A brass coin), which was first manufactured during the fourth year of reign of King Gojong of Chinese Tang Period(A. D. 621), was discovered in an urn. Literature about cremation of Shilla was from documents of Samgukyusa(the Heritage of the Three States) and origination of Shilla cremation is estimated the beginning or middle of the seventh century(Park, 2008). It is possible to know that cremation was used for processing corpses during the period of the Three States(Chang, 1984).

\subsubsection{The period of unified Shilla}

During the period of unified Shilla, it was recorded that King Munmu had left a will about his own funeral ritual procedure after death and commanded to "have cremation funeral according to an Indian Buddhism custom in the field outside of the palace when it lapses 10 days after death." After the cremation of King Munmu(In 681), those kings, who were documented to have had cremation in Samguksagi(the Chronicles of the Three States) and Samgukyusa(the Heritage of the Three States), were King Gyoseong, King Seondeok, King Wonseong, King Jinseong, King Hyogong, King Seondeok and King Gyeongmyeong(Chang, 1984). Therefore, it is believed that cremation became expanded in all classes of the society ranging from royal families to the common people and was popular until 935 when Shilla was collapsed.

\subsubsection{The period of Goryeo}

Goryeo had Buddhism as the national policy and funeral method was per cremation method of Buddhism. Procedure of cremation was composed of three courses of cremation, repose and burial of skeletal bones. Cremation was mainly carried out generally at nearby slopes of mountains. Cremated remains were stored temporarily at temples primarily and this was called as a repose and during the period, descendants prayed for an easy passing into eternity and mourned deaths of ancestors every morning and evening. When the repose period is terminated, skeletal bones were buried and burial of bones meant to bury sealed remains in temples into the ground(Kim, 2005).

Cremation during the period of Goryeo had continued until the time of King Injong, King Euijong and King Myeongjong. After that, Mongolian invasion started and after the reign of King Chungryeol, Buddhism style funeral ritual formalities were prohibited due to the introduction of the doctrines of Chu-tzu. According to the recommendation of Chu-tzu scholars, who had insisted enforcement of the four ceremonial occasions of coming of age, wedding, funeral, and ancestral rites for family rites, prohibition law of cremation went effective from the end period of Goryeo, to the period of Joseon(Lee \& Park, 2002). After all, insistence of
Confucian ancestral ritual formalities according to the doctrine of Chu-tzu by noblemen, who had recommended depression of cremation and encouragement of burials, had prohibited Buddhism style cremation and had realized implementation of soil burial and three-year mourning funerals according to family rites of Chu-tzu. As a result, a drastic momentum of change to provide ancestral rites for all noblemen and common people was brought up by setting up family grave sites(Nam, 2002). Therefore, it is possible to know that cremation had gradually decreased and burial custom had been expanded after the period of Goryeo(Chang, 1980).

\subsubsection{The period of Joseon}

King Taejo, who was the founder of Joseon dynasty, had commanded to have funeral rituals following Chu-tzu family rites while adopting the policy of depressing Buddhism and encouraging Confucianism. However, cremation, which was continued from the period of the Three States, was not changed easily only through Confucian enlightenment of ideology. New funeral rituals of burials were built upon powerful control and punishment. The evidence of such a fact can be found out in authentic records of King Seongjong as it was described in April of the fifth year of reign of King Seongjong as follow; "Recently, ignorant common people cremate corpses of their parents as being deceived by a cunning monk or not to pay for burial equipments. Also they dig out tombs of their ancestors and burn them as they believe their sickness was originated from their ancestors or parents when they are sick. But all of these behaviors are damaging good customs and disturb reformation. Therefore, cremation of their parents was strictly prohibited and the government officers, and even their close neighbors, who failed to arrest violators, were all severly punished."(Kim, 1993). Judging from this, it is believed that a cremation system, which was very popular until the end period of Goryeo, was changed into burial culture throughout the period of Joseon because of strict enforcement of the regulations of punishment and penalties by the prohibition law of cremation. And funeral ritual culture of Korea was changed drastically.

\subsubsection{The period of Japanese Invasion}

As a part of the policy to destroy Korean national consciousness, Japan had changed Korean cemetery system into a joint cemetery as Korea was ruled by forced control by Japan. Cremation methods, which were prohibited during the period of Joseon, were revived again(Lee \& Gwak, 2006). However, authority for cremation was mainly focused on colonial exploitation rather than emphasizing advantages of cremation. Throughout the period of Japanese ruling, rejection feeling of Korean people about cremation had been increased more and more. After the independence in 
1945 , behaviors of cremation were limited to burning of corpses and Korean people have avoided cremation except special cases of wills by death people, patients of epidemic diseases, death people on streets or by accidents, and stillborn babies, etc(Lee \& Lee, 2011). As a result, it is believed that it had become the biggest reason for rejecting cremation culture which had existed from the period of the Three States.

\subsubsection{Modern period}

Family rite standards announced in 1934, family rite standards of 1961 and enactment of family rite standards in 1969, etc had become a momentum to drastically simplify procedure of funeral rites and shrouds system. In addition, funeral homes have taken the role of funeral rites as the result of adaptation to urban life style in urban society these days(Song, 2010). As use rate of joint cemetery or crematorium has been increased, Confucian style funeral rites have been simplified. In several universities, departments of funeral instruction were opened about 10 years ago for training young students succession of funeral culture and full implementation of their duties as funeral instructors. Together with this, activation of using funeral homes also means forewarning of changes of our funeral culture(Chang, 1980).

People's consciousness of funeral culture in modern period makes people to request to change funeral culture as $1 \%$ of the national territory has become cemetery, which is equivalent to three times of Yeoeuido. Koreans will suffer finding burial sites in 10 years of the future and it is recognized that efficient utilization of the national territory will become difficult because of this("Improvement and Forecast of Modern Funeral Culture", 1994).

In case of the ratio of cremation of foreign countries, it is in a trend of gradual increase with $12 \%$ in the USA, $70 \%$ in England, $70 \%$ in Swiss, $64 \%$ in Sweden, $97 \%$ in Japan, $95 \%$ in Thailand and $47 \%$ in Taiwan, etc.

Cremation rate of Korea was about $10 \%$ in 1970s but it had been gradually increased due to the policy of the national improvement of funeral culture started after middle of 1990s. In 2005, for the first time, cremation rate surpassed burial rate and in 2009 , cremation rate showed the national average rate of $65 \%$. In 2012, it was investigated that Korean burial rate reached $70 \%$ while big cities showed $80 \%$ and Jeju showed 50\%("'Issues of Funeral Culture of Jeju Island", 2012).

\subsection{Jeju's culture of funeral rituals}

Jeju's culture of funeral rituals has characteristics different from other regions. It was from the 15th century in the beginning of Joseon Kingdom when Confucian culture of funeral rituals was introduced in Jeju Island. It can be said to be from the 18th century in the late period of Joseon Kingdom or the 19th century when the Confucian culture of funeral rituals was proliferated and settled. Confucian culture had settled down as new dominating culture by replacing existing indigenous culture based on shaman faith passing throughout a long time as the Confucian culture of funeral rituals had assimilated with the environment of Jeju Island(Chung, 2008). In the process, a certain change had been experienced in its forms and contents as the Confucian culture of funeral rituals had met with the history and environment peculiar to Jeju Island. Confucian culture of funeral rituals also shows different characteristics. They are conducting styles of funeral rituals while respecting traditional Confucian style ritual forms, a custom of receiving outside condolers only on a day of good eating(Ilpo day), joint sharing of the cost of funeral ritual and a custom of performance of shaman ritual(Gwiyangpuli) on funeral day, etc. This culture of funeral rituals is tradition, which was originated through assimilation between Confucian ritual and shaman ritual after the period of Joseon and affected from local natural characteristics of culture. It is continuing until today.

\subsubsection{Jeju's rural culture of funeral rituals}

During 2000s, culture of funeral rituals of Jeju's farm villages are changing in majority parts. Period of funeral rituals has been shortened rapidly and experts hosting funeral rituals who existed in each village disappeared and professional funeral homes are now processing matters related to funeral rituals as they penetrated into all villages within Jeju Island. Funeral ritual was a personal as well as a joint event of a village and through this, norms of communities were generated and maintained but now, even this phenomenon is weakening. Weakening of ideology of feng shui and respect of ancestors have significantly affected funeral culture and use of a village joint cemetery becomes prevalent and phenomenon of finishing funeral rituals in cremation and charnel house is increasing. Play culture such as bier sound, ground rammer(Dalgu) sound, etc has disappeared as bier was abolished and food of funeral ritual, which was tradition, is also disappearing as it is modernized. These changes are closely related to the phenomenon of dismantling of farm village communities and it is expected that more rapid changes will take place in the future("Issues of Funeral Culture of Jeju Island", 2012).

However, partially, there remain various elements of folklore belief in funeral rituals of Jeju Island and as representative phenomena, there are performance of shaman ritual(Gwiyangpuli), serving one dish(Iljeob), individual condolence donation, etc while one good eating day(Ilpo) is an important day. In addition, the phenomenon to observe procedure and custom of funeral ritual is continuing. Unlike the custom of three-day funeral culture in cities, in 
farm villages, funeral rituals according to traditional custom and norms are still carried out.

\subsubsection{Shrouds of Jeju}

\subsubsection{Jeju traditional shrouds}

Even in Jeju, shrouds are mainly produced during leap years and leap months. Leap months are called as empty months and were selected under the meaning of blessing. It was also believed that people live longer and even sick people become healthy if shrouds are produced when people are old before death(Nam, 2007).

In a method of producing shrouds, it was distinguished partially from other regions and its traditional method of production has passed down generations from artisans of cut method peculiar to Jeju. Shrouds are mainly produced by requesting people blessed a lot to sew by hand. Tying a knot and backstitching were never allowed. It means one's desire for the dead to pass away by solving all bounds made in this world and for going to other world safely without looking back a life in this world. The number of dimension or width(width of skirt) was in odd number. It means not to look for address when going to other world. People believed that life and death all return to land. Majority of Jeju's old people recognize that traditional shroud form must be considered in the meaning of respect for dead people and wishing prosperity of their descendants.

Jeju women put on clothes they put on during wedding on their 60th birthdays. They also put on their wedding clothes as their shrouds when they pass away. Therefore, they have special inherent consciousness about shrouds. Women put on silk Jangot(a kind of long hood formerly worn by Korean women) shrouds. As they used clothes they put on during wedding ceremonies after keeping them with care, they wanted to put on clean and beautiful shrouds however poor they may be because they believed that death is another beginning of a new life(Fig. 1).

Men put on shrouds Dopo(Korean full-dress attire for men) they put on during wedding ceremonies and even farmers put on Dopo, which is clothes of noblemen, when they die. These are recorded documents which are a little different from other regions(Dopo, 2000). In producing one suit of shrouds, five rolls of silk are used and if all five rolls are not used, it was not considered as a pro- pitious funeral. It takes full five days for an artisan equipped with the skill to produce one suit of shrouds. In a working place of producing shrouds we visited, there were eight grandmothers and cut was done by one grandmother who owned the skill and other grandmothers were finishing the production of shrouds in division of works of machine sewing and needlework.

Kinds of shrouds we saw there were formidable in its numbers of one suit of shrouds. They were more than 20 kinds such as Korean style mattress used as a bed on the floor, blanket(A green neckband is put around for men and a red neckband is put around for women), pillow, underpants(Sojungi : underwear for women) (Fig. 2), Ddambadae(patch gusset), Jeoksam(an unlined summer jacket), Jungi(unlined) Jeoksam(summer jacket of women), Jeogori(upper garment of Korean traditional women clothes: two sets of clothes for women) and trouser(Trouser Jungi and two sets of skirts for women), Daenim(ankle band), Beoseon(Korean socks), Aksu(hand wrapping cloth), Eomdu covering the head and

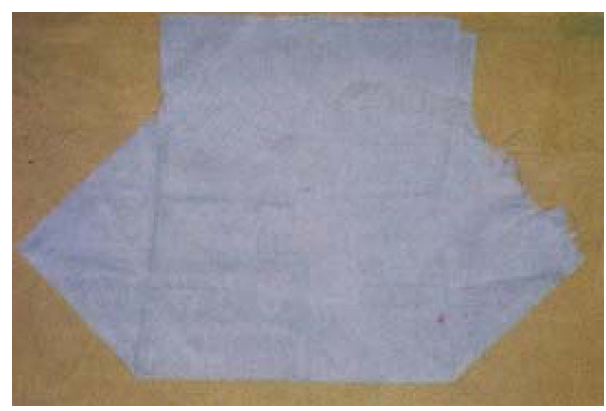

Fig. 2. Sojungi.

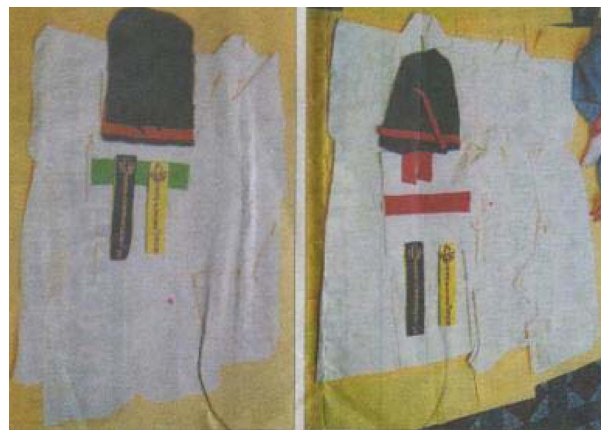

Fig. 3. Myeongmok.
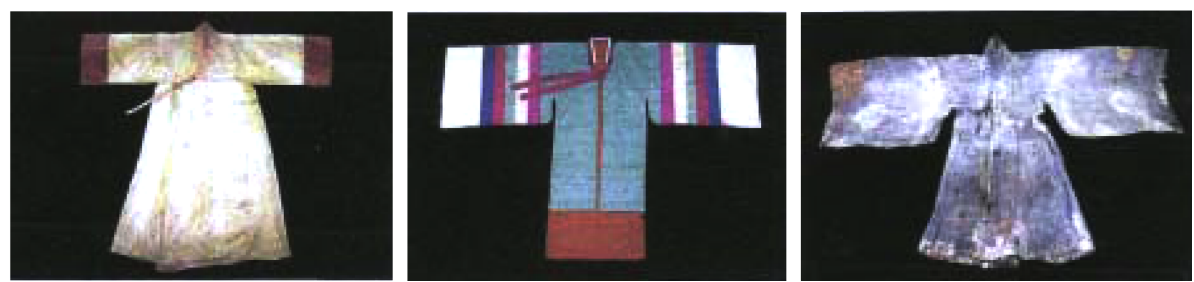

Fig. 1. Jangot. The dress and it's ornament of Jeju (2010), p.168. 
Myeongmok(closing eyes) covering the face(Fig. 3).

(black color outside and red color inside)Outside black color means severance asking to forget matters of this world and inside red color means one's wishes for prosperity of their descendants in the future(For men, it is a simple rectangular shape and for women, which is called as 'Pungdeongi(beetle)', it is a delicate round shape with the attachment of two strings of Daenggi(ribbon on the back), five pockets containing hair, clipped fingernails of right and left hands and clipped toenails of right and left feet of a dead person, Gwadi(a band/belt to tie the waist), Changot(men's upper dress with large sleeves and opening without buttons), Dopo for men, Jangot for women(Fig. 3), Dureumpo(wrapping cloth) and Dongsimjul(a cord tied from the same core) (It is believed that a dead person goes to other world when Dongsimjul is included in a coffin), etc. For production of shrouds, people paid all their sincere attentions to all matters ranging from selecting silk, producing shrouds and up to storing after folding well. Even when we count the number of kinds and sequence of making one suit of shroud with formalities, it takes a long time. Grandmother Kim SaengGyong(94 years old), who is an artisan of indigenous cultural property designated by Jeju city in the field of shrouds, said it takes at least two years to pass down method of cut and production of shrouds and we could imagine how difficult 'production of shrouds' was.

\subsubsection{Change of consciousness about Jeju shrouds}

In Jeju, where Confucian ideology is stronger than other regions and people appreciate tradition and custom more importantly, cremation was avoided from the perception of killing ancestors two times("Issues of Funeral Culture of Jeju Island", 2012). However, according to the national policy encouraging cremation, Jeju's farm villages are rapidly increasing cremation.

For Jeju people, preparation for going to other world, that is, to have a good dying, was as important as having a good life in this world. Therefore, they insist to produce shrouds with silk which is not only expensive but also difficult to cut properly. In case of silk shrouds, they believed that silk is the best for decaying corpses after burials and thus they used the most expensive and luxurious fabric as the highest respect for dead people. In particular, ramie cloth, cotton swab and cotton are absolutely prohibited. It was because they believed that ramie cloth makes their descendants have prematurely gray hair and cotton swab and cotton make corpses to become dark black color when corpses are decayed. Theses are all consciousness regarding shrouds related to burials.

However, despite changing culture of funeral rituals into cremation, there are requests of changes regarding the current status of funeral rituals due to an issue of lacking grave sites more and more day by day, natural damages of rain and wind, damages of corpses by invasion of tree root and insects and indifference of descendants. As a funeral ritual form is recognized globally, cremation culture could not avoid the necessity of changes of shrouds put on dead people until now accordingly. Shrouds are barely surviving with traditionality and conservatism but just like other regions, even in Jeju, changes of consciousness about shroud is taking place. Funeral ritual procedure has been changed and simplified a lot and now production works of shrouds with proper numbers of all required items are disappearing. However, in Jeju's farm villages where it is still conservative, cut and production of the shroud is performed by selecting a proper day according to Sajupalja(Four pillars and eight letters which determine one's destiny) of a person who will put on shrouds. It meant that people prepared shrouds equipped with formalities by paying sincerity and even by containing wishes of next world. Few people, who know importance and meaning of shrouds, are ordering special tailor-made shrouds. It seems like that production of customary shrouds of tradition is maintained sparingly.

\section{Result}

Reason for attempting interviews by dividing interview period into two times was because it was intended to observe continuously the whole process of making shrouds. As a result, shrouds manufacturing was processed steadily at the same place(Dong office of Ido-Dong) and it is believed that traditional shrouds of Jeju Island still remain as an important part of consciousness of Jeju people. Also, as it was believed to become an important clue in examining whether or not of changes of consciousness, the two different interviews with each different interview time were analyzed all together without separating the data.

Among interviews with people of Jeju farm villages in their forties-seventies, people except in their forties were positive about traditional shroud of Jeju and even for cremation, they have

Table 1. Interview questionnaires

\footnotetext{
1. Do you know that shrouds of Jeju Island are different from other regions?

2. Did you prepare your own traditional Jeju shroud? or Do you plan to prepare your own in the future?

3. Do you think that Jeju traditional shrouds must be preserved and Jeju people should use continuously in the future?

4. Do you think it is okay to use shrouds sold at commercial funeral houses as your own shroud?

5. What do you want your children to do about your funeral?
} 
recognition that silk material shroud is the best. From Jeju custom considering silk shroud as the best because of the meaning that corpse is decayed well, Jeju people also regard silk as the best shroud material because it burns very well even during cremation. In Jeju farm villages, people are still attached to Jeju traditional shroud very much. People still show negative recognition about hemp cloth shroud and it is believed that people showed negative reaction as lots of hemp cloths are imported from China. Seven people in their sixties and seventies have shrouds they have prepared by themselves and three persons in their fifties have plan to prepare shrouds in the future. Two persons in their forties answered that they are not interested in Jeju shrouds.

As the result of the examination, cremation became more negative as remaining practice of Japanese ruling and until now, people have aversive feeling about cremation because of dust and bad odor due to poor cremation facilities. As the result, phenomenon of NIMBY(Not In My Back Yard) not allowing construction of cremation facility in my region and our regions by regarding cremation facility as unpleasant facility is emerging. Nevertheless, because of consciousness for appropriateness of cremation and government policy, rate of cremation is increasing steadily. In particular, we could find out that our funeral culture is changing completely since after activation of using funeral homes in modern period("Survey of Consciousness on Funeral Culture", 2008).

In traditional society of the past, burial culture according to complex rituals procedure was prevalent due to impacts of folk religion and Confucian norms.

However, since after mid 1980s, as practices of having funeral rituals at hospital mortuary or funeral homes were rapidly proliferated, traditional ethical belief and formality during the courses of funeral have been changed due to mixture of traditional view of life and death focusing on contemporary time and western secularism and individualistic values. Consequently, people's consciousness also has been changed rapidly. Besides, opportunism centering on growth of individualism and young people, improvement of women position in society and changes of a family system, etc have weakened funeral rites based on patriarchy. And new consciousness for new funeral rites is appearing because increase of cemetery according to funeral rituals focusing on burial has damaged natural landscape and also deteriorates efficient use of the national territory including procurement of industrial lands, etc. Consequently, it brings about changes of values and culture regarding funeral rites. According to existing theses which insist on changes of consciousness while burial culture until now must be changed into desirable cremation culture, majority of people showed response that we need to improve funeral system. As the contents required to change the consciousness, people are pointing out excessive expenditure of costs, getting rid of negative opinion about cremation and an issue of cemetery, etc.

Recently, as the number of cemetery increases continuously, cemetery becomes obstacle for use of the national territory and it is estimated that natural burials, which do not require lands, will become more popular gradually. There are largely two kinds in natural burials. Burial type natural burials are methods to directly bury corpses under trees or to plant trees above buried corpses and to bury corpses surrounding trees of existing forest without burial mounds or tombstones and were mainly carried out in England. Skeletal bone type natural burials are methods to bury under or around trees by containing in an environmental decomposition type bag after crashing remains finely and are mainly carried out in Japan. This method is believed to become popular even in Korea because it can be implemented freely even in regions without permission as a cemetery unlike burial type natural burials. Since natural burials, vegetable garden burials and flower bed burials are allowed even in Korea upon preparation of detailed regulation plans of funeral ritual law with a new concept according to the social demand("Survey of Consciousness on Funeral Culture", 2008), it is expected that various environmentally natural funerals will be increased in the future.

\section{Examination}

Jeju's rural culture of funeral rituals is rapidly changing starting from the beginning of 2000s. After 1960s, the government had tried to change culture of funeral rituals but conservatism of agricultural societies did not easily accept. Moreover, they tried to preserve their traditional custom and culture for a while by protesting against the government administration. However, gradual changes even inside of agricultural societies are being established. Such a change can be explained as one phenomenon showing dismantling of communities. Changes of agricultural societies will be accelerated more due to replacement of the generation maintaining rural communities, changes of traditional values, weakening of existing tradition and urbanization of rural culture, etc. Jeju people called shrouds as 'Hosangot(shroud clothes)' and they wished to have the most luxurious shrouds in the belief that dead people can solve all miseries of this world in other world where all people are equal. However, as culture of funeral rituals is changed, it is difficult to produce or order tailor-made Jeju's unique shrouds and therefore, its tradition is only surviving in minimum extent. As the result of interviews with senior people of farm villages, they strongly think not to give burdens to their children and recognize realistic difficulty of taking care of grave sites and subsequently, they have interest in the campaign of leaving wills of cremation and etc. As people 
in Jeju farm villages still have positive recognition about traditional Jeju shrouds, they answered that silk is the best material for shrouds even if they are cremated. In Jeju's funeral homes, a corner of selling traditional Jeju shrouds is also established. These examples tell that there are people who have no big changes of consciousness of traditional shrouds with regard to death and as ages are younger gradually, consciousness about shroud become unclear.

Due to the limit of this research, as survey was carried out only in restricted area of Jeju's farm villages, it is worried for a broad interpretation as a whole. However, it is estimated that consciousness about shrouds will be changed drastically together with the changes because our shrouds are deeply related to the culture of funeral rituals of the time. As values for funeral rituals are changing and the space of funeral rituals is changed from one's home to hospitals or funeral homes, people select general shrouds recommended by commercial funeral homes, it is believed that the concept of Jeju's traditional shrouds, which contains even wishes for next world in addition to handcrafts with full sincerity, will disappear sooner or later. The contents not presented in this research will be developed and presented through successive researches after examining composition method of producing unique shrouds of Jeju Island. In addition, new questionnaire survey based on this research will be expanded to include more people and study on their perspectives about the world after death will be supplemented.

\section{Acknowledgement}

This research was supported by the 2013 scientific promotion program funded by Jeju National University.

\section{References}

Chang, C. S. (1980). A study on traditional four ceremonial occasions of coming of age, wedding, funeral and ancestral rites of Korea. Korean Society and Culture 2, The Academy of Korean Studies.

Chang, C. S. (1984). The four ceremonial occasions of coming of age, wedding, funeral, and ancestral rites of Korean traditional society. Unpublished master's thesis, The Academy of Korean Studies, Seoul.
Cho, H. S. (2002). Shrouds culture of Korea: desirable shrouds culture of contemporary society. Seoul: Books Publisher Shinyu.

Chung, H. J. (2008). The study of the characteristics and changes of funeral-rite's culture in Je-ju rural society. Unpublished master's thesis, Jeju National University, Jeju.

Chung, J. S. (1990). Korean funeral rituals. Seoul: Mijin Company. Improvement and Forecast of Modern Funeral Culture. (1994, April 7) The Chosun Daily Newspaper, p. 7.

Issues of Funeral Culture of Jeju Island. (2012, May 12). The Jemin Daily Newspaper, p. 6.

Jeju National University Musium. (2000). Jeju dressing. Jeju: Jeju National University.

Jeju National University Musium. (2010). The dress and it's ornament of Jeju. Jeju: Jeju National University.

Kim, H. J. (1993). Life and Death of Korean People. Seoul: Sigma.

Kim, J. S. (2005). Korean translation of Chu Tzu Family Rites. Unpublished master's thesis, Seonggyungwan University, Seoul.

Lee, E. J., \& Gwak, M. S. (2006). Culture and Composition of Shrouds. Gyeongchun: Publisher Gyeongchun Company.

Lee, J. S. (1990). Gwanhonsangje (the four ceremonial occasions know definitely (Y. J. Song, Trans.). Publication. (Original work published 1983) of coming of age, wedding, funeral, and ancestral rites) we should

Lee, S. H., \& Lee, J. Y. (2011). A study on the effects of the view of afterlife on people's perceptions about shrouds. Journal of the Korean Society for Clothing Industry, 13(3), 321-331.

Lee, Y. G. (2006). Traditional Gwanhonsangje (the four ceremonial occasions of coming of age, wedding, funeral, and ancestral rites). Reseach Institute of Korean Traditional Ceremonies, 12(2), 421-431.

Lee, Y. J., \& Park, S. S. (2002). Shrouds Culture of Korea: A Historical Reflections on Shrouds During Joseon Period. Pusan: Books Publisher Shinyu.

Nam, M. I. (2002). Science of Funeral Rituals. Seoul: Sigma Press. Nam, M. I. (2007). Producing Shrouds. Seoul: Woori Publication.

Park, H. C. (2008). Gwanhonsangje (the four ceremonial occasions of coming of age, wedding, funeral, and ancestral rites) and its root. Seoul: Dongshin Publication.

Survey of Consciousness on Funeral Culture. (2008, July 15). The Joongang Daily Newspaper, p. 10.

Yang, S. I. (2010). Funeral Rituals of Korea: Multidisciplinary Introspection Regarding Life and Death of Koreans. Seoul: Hangil Company.

(Received 27 November 2012; 1st Revised 3 April 2013; 2nd Revised 10 April 2013; 3rd Revised 17 April 2013; Accepted 20 April 2013)

Copyright (C) The Society of Fashion and Textile Industry. 2013. This is an open access article distributed under the terms and conditions of the Creative Commons Attribution Non-Commercial license (http://creativecommons.org/licenses/by-nc/3.0/), which permits unrestricted non-commercial use, distribution, and reproduction in any medium, provided the original work is properly cited. 